\title{
PENGARUH PROMOSI DAN KUALITAS PELAYANAN TERHADAP KEPUASAN KONSUMEN PADA RESTORAN BAKSO LAPANGAN TEMBAK SENAYAN
}

\author{
Diana $^{1}$, Nanda Harry Mardika ${ }^{2}$ \\ ${ }^{1}$ Mahasiswa Program Studi Manajemen, Universitas Putera Batam \\ ${ }^{2}$ Dosen Program Studi Manajemen, Universitas Putera Batam \\ Email:pb160910088@upbatam.ac.id
}

\begin{abstract}
The development of business today is characterized by increasingly intense competition, to be able compete with other culinary businesses, companies must pay attention to promotions, service quality and customer satisfaction. Attractive promotions and good service quality can increase customer satisfaction. The purpose of this study was to determine the existence of a positive and significant effect between promotion variables and service quality on consumer satisfaction at the Restoran Bakso Lapangan Tembak Senayan with a purposive sampling technique, the number of samples in this study amounted to 100 respondents. Data collection method is questionnaire. Data quality in this study uses validity and reliability test, the classic assumption and the influence test in this study using multiple linear regression analysis and coefficient of determination analysis (R2), while the hypothesis testing in this study uses $t$ test and $F$ test using SPSS version 23 software program. The results of the t test and F test, it can be concluded promotion is partially positive and significant effect on customer satisfaction, service quality is partially positive and significant effect on customer satisfaction, as well promotion and service quality as a whole. simultaneous positive and significant effect on consumer satisfaction in the Restoran Bakso Lapangan Tembak Senayan.
\end{abstract}

Keywords: promotion, service quality, customer satisfaction

\section{PENDAHULUAN}

Usaha kuliner sangat kompetitif karena hal terpenting yang harus dimiliki manusia untuk menjadi tren bagi masyarakat. Persaingan yang kuat antara perusahaan riset dengan perusahaan lain memungkinkan perusahaan riset untuk mempertimbangkan strategi yang kuat untuk mengelola persaingan. Untuk menjadi pemenang dalam persaingan, perusahaan wajib 
memahami apa yang menjadi kebutuhan, keinginan dan tuntutan konsumennya. Dengan memahami kebutuhan, keinginan dan tuntutan konsumen, maka akan memberikan masukan yang sangat berharga bagi perusahaan dalam perancangan strategi pemasaran yang dapat bertahan agar memuaskan konsumen dan bersaing di pasar.Untuk mencapai tujuan ini, setiap bisnis menggunakan aktivitas komersial untuk menghasilkan makanan berkualitas dan memastikan kepuasan konsumen yang akan menguntungkan bisnis dalam jangka panjang.

Dalam bersaing banyak hal yang dipertimbangkan perusahaan, seperti

geografis,distribusi,demografi dan lainnya. Tanpa terkecuali perusahaan PT. Sri Indah Mekar Sejati. PT. Sri Indah Mekar Sejati berdiri pada tahun 2007 yang berlokasi di Komplek Sei Panas Tanah Mas blok M nomor 4 Kota Batam. Perusahaan yang bergerak dibidang kuliner memiliki persaingan pada segmentasi pasar yang sama. Perseroan ini merupakan usaha franchise restoran "Bakso Lapangan Tembak Senayan".

Promosi adalah faktor yang harus dipertimbangkan perusahaan untuk memuaskan kepuasan konsumen. Promosi merupakan aspek terpenting dari penjualan.
Bauran pemasaran menghasilkan umpan balik konsumen, sehingga konsumen dapat memberikan penilaian terhadap promosi secara langsung maupun tidak akan menciptakan citra nama merek yang baik dan bagus terhadap suatu produk atau jasa tersebut. Pernyataan ini di dukung oleh (mardizal, 2017:130) Semua kegiatan promosi dirancang untuk memengaruhi perilaku pembelian, Tetapi tujuan utama promosi adalah untuk memberi informasi,membujuk dan memperingatkan konsumen tentang produk. Dengan adanya promosi diharapkan konsumen dapat membuat keputusan apakah akan membeli atau tidak.

Ada tiga jenis penyampaian promosi yang dilakukan oleh restoran bakso lapangan tembak yaitu brosur fotocopy, pengiklanan pertama buka restoran menggunakan media televisi, dan sosial media facebook. Kuantitas yang dilakukan untuk brosur fotocopy sebanyak 3 kali. Pembagian brosur fotocopy dilakukan pada tempat keramaian seperti didekat eskalator mall, depan supermarket, dan tempat keramaian lainnya. Untuk pengiklanan pertama buka restoran menggunakan media televisi dilakukan hanya sekali pada saat peresmian dan pembukaan untuk pertama kalinya. Pengiklanan 
tersebut hanya dilakukan sekali karena tujuan dari restoran hanya sebatas memberitahukan bahwa adanya opening atau pembukaan restoran bakso lapangan tembak di mall tersebut. Penyampaian promosi menggunakan sosial media facebook hanya dilakukan dua kali karena kurangnya karyawan atau admin yang khusus mengelola akun sosial media restoran bakso lapangan tembak, dan oleh karena itu juga penyampaian promosi yang dilakukan hanya pada sosial media facebook padahal seperti yang diketahui bahwa terdapat berbagai jenis sosial media seperti instagram, twitter, dan lain sebagainya. Kemudian kualitas penyampaian promosi yang dilakukan sebagai contoh dapat dibahas brosur yang difotocopy, karena fotocopy otomatis kualitasnya kurang karena brosur yang difotocopy buram, dan kurang menarik konsumen karena berwarna hitam putih sehingga pesan promosi yang ingin disampaikan menjadi kurang tersampaikan.

Kualitas pelayanan sangat penting karena layanan yang baik menentukan kepuasan konsumen. Kualitas pelayanan bertujuan untuk memudahkan konsumen memahami bahwa konsumen lebih berharga dari yang mereka harapkan dan inginkan. Harapan konsumen adalah faktor penting dan kualitas pelayanan yang dekat dengan kepuasan konsumen memberi lebih banyak harapan dan sebaliknya. Pernyataan ini di dukung oleh (Aswad, Realize \& Wangdra , 2019:79) Kualitas pelayanan adalah Perilaku yang dilakukan oleh penyedia barang atau jasa untuk diberikan kepada orang yang membutuhkan barang atau jasa yang dapat nilai tersendiri dari orang tersebut. Bila kualitas pelayanan yang diberikan kepada konsumen dapat dicapai, konsumen akan lebih puas jika memenuhi harapan. Perusahaan perlu mengembangkan strategi kualitas pelayanan untuk mempertahankan konsumen,ketika konsumen puas tentunya mereka akan melakukan pembelian ulang.

Faktor kualitas pelayanan harus di perhatikan oleh perusahaan dengan menganalisa keluhan konsumen misalnya pelayan kewalahan dalam melayani konsumen yang datang secara bersamaan pada waktu ramai dan jumlah pelayan yang melayani konsumen pada saat waktu ramai dan waktu senggang sama. Pada saat ramai konsumen ingin melakukan pembayaran terkadang sulit menemukan kasir ,karena kasir juga menjadi pelayan untuk melayani konsumen. Ketika ramai makanan yang di pesan oleh konsumen lambat terhidangkan,sehingga konsumen melakukan komplain. 
pada tahun 2018 hingga bulan september tahun 2019 jumlah komplain terhadap kualitas pelayanan mengalami peningkatan seperti pada tahun 2018 jumlah komplain untuk kecepatan pelayanan sejumlah 55 sedangkan pada bulan januari hingga september tahun 2019 sejumlah 61 . Hal ini menunjukan bahwa kualitas pelayanan semakin menurun sehingga dapat mengakibatkan konsumen kurang puas terhadap pelayanan dan pindah ke restoran lain.

Untuk bertahan lama dalam bisnis kuliner kita perlu memperhatikan kepuasan konsumen.Kepuasan konsumen adalah faktor kunci dalam mempertahankan bisnis agar berhasil dalam persaingan yang ketat.Harus memberikan sesuatu yang bernilai dan berkesan terhadap konsumen.Dengan kata lain,kepuasan diberikan oleh pelayanan yang sesuai dengan kualitas produk dan pelayanan yang diberikan.Pernyataan ini di dukung oleh (Hermawan, Basalamah, Djamereng, \& Plyriadi, 2017:64) bahwa kepuasan konsumen sekarang menjadi bagian dari tujuan perusahaan dan kualitas layanan untuk perusahaan menjadi sangat penting untuk memberikan kepuasan lebih kepada pelanggan dan pada akhirnya menambah nilai bagi perusahaan.
Penjualan restoran bakso lapangan tembak senayan tidak stabil, Bila dilihat dari pertumbuhan ekonomi dan inflasi di Indonesia maka dapat dikatakan penjualan restoran bakso lapangan tembak senayan tidak mengalami peningkatan. Sebagai contohnya sejak september 2018 hingga november 2018 penjualannya stagnan berada diangka 500 jutaan namun mengalami peningkatan yang cukup tinggi pada bulan desember 2018 yang berada diangka $\mathrm{Rp}$ 786.471.912. Pada bulan januari 2019 mengalami penurunan yang cukup signifikan yang berada diangka $\mathrm{Rp}$ 476.932.180. Kemudian pada bulan februari hingga september 2019 penjualannya kembali stagnan berada diangka 400 juta hingga 500 juta. Yang menyebabkan penjualan yang tidak stabil karena promosi kurang menarik dan kualitas pelayanan yang tidak dapat memuaskan konsumen. Penyampaian promosi yang dilakukan cenderung kurang menarik dan kuantitas yang sedikit jumlahnya seperti yang terlampir pada data penelitian serta penjelasan mengenai promosi yang kurang kuantitas maupun kualitasnya. Kemudian kualitas pelayanan yang menurun dapat dilihat dari data komplain dari konsumen menjelaskan bahwa tingkat komplainan konsumen terus 
meningkat pada setiap tahunnya sehingga dapat disimpulkan bahwa kualitas pelayanan restoran bakso lapangan tembak mengalami penurunan sehingga dapat dikatakan bahwa kedua faktor ini yang menyebabkan kurangnya kepuasan konsumen saat mengunjungi restoran yang menyebabkan penjualan yang tidak stabil dan terus menurun.

\section{Promosi}

\section{KAJIAN TEORI}

Promosi yang dikemukakan oleh (Manampiring, Tumbuan, \& Wenas, 2016:166) yaitu promosi adalah elemen pemasaran yang tidak boleh diabaikan dalam proses penjualan. Upaya untuk mempromosikan produk diperlukan untuk mendukung penjualan produk,menyediakan produk kepada konsumen dan mendorong konsumen untuk membeli produk. Banyak orang terlalu mengabaikan promosi ini dan merancangnya tidak dengan baik-baik, padahal promosi bisa menjadi suatu hal yang akan diingat oleh orang-orang yang menjadi calon konsumen kita. Semua berawal dari promosi, promosi ini bisa menjadi jembatan untuk perusahaan dengan calon konsumen untuk menjadikan calon konsumen menjadi konsumen. Setelahnya ketika calon konsumen menjadi konsumen kemudian tugas yang harus dilakukan selanjutnya adalah memastikan promosi yang ditawarkan sebelumnya sesuai dengan yang ditawarkan sebelumnya agar mendapatkan kesan yang baik dari konsumen tersebut. Yang sering terjadi dan yang dirasakan oleh konsumen adalah bila datang dan ingin menikmati makanan promo maka jangan berharap dapat menikmati porsi yang sesuai dengan regular atau dengan kata lain karena promosi jadi porsinya dikurangi. Untuk permasalahan dan pola pikir konsumen terhadap pebisnis kuliner atau makanan yang buruk mengenai itu, maka tugas kita adalah menghilangkan pola pikir tersebut untuk mengurangi penilaian yang buruk dari konsumen. Jadi untuk pebisnis kuliner jangan memberikan promosi namun tidak sesuai dengan yang ditawarkan ataupun porsi promosi menjadi tidak sesuai dengan regular yang mengecewakan konsumen. Yang perlu diingat adalah bila konsumen sekali dikecewakan maka sangat sulit untuk membuat mereka percaya kembali kepada kita, oleh karena itu jangan sekali-sekali mengecewakan konsumen.

\section{Indikator Promosi}

Menurut (Pelupessy, 2018:108) Beberapa indikator dalam promosi adalah sebagai berikut.

1. Jangkauan promosi merupakan penerkaan jumlah total pemakai 
pada suatu demografi dan geografi, sesuai dengan jumlah pemakai yang masuk.

2. Kuantitas penayangan iklan di media promosi merupakan seberapa lumrah dan seberapa biasa iklan promosi yang dipaparkan pada media promosi seperti : majalah, media elektronik, tv, dll.

3. Kualitas penyampaian pesan dalam penayangan iklan di media promosi merupakan pesan promosi yang di nilai berkualitas apabila mampu mendapatkan perhatian dan mempertahankan minat.

\section{Kualitas Pelayanan}

Kualitas pelayanan adalah format yang melukiskan status pengguna atau konsumen pada suatu bentuk harapan yang asalnya dari pengalaman pribadi dari orang tersebut, informasi dari mulut ke mulut dan servis yang diharapkan dengan yang diterima apakah sesuai atau tidak. (Roring, Oroh, \& Gulla, 2015:1313). Kualitas pelayanan ini tidak dapat dianggap remeh dalam bisnis makanan, selain dibutuhkan makanan yang memang lezat akan tetapi kualitas pelayanan ini sangat penting meskipun makanan yang lezat namun bila pelayanan yang diberikan tidak baik maka konsumen akan merasakan atau mencari alternatif yang lain untuk menikmati suatu hidangan. Kualitas pelayanan yang dimaksud disini yang diberikan oleh semua yang berada didalam bisnis kuliner tersebut seperti pelayan yang berada digaris langsung melayani konsumen bila konsumen membutuhkan sesuatu pasti sampaikan kepelayan terdahulu bila pelayan tidak secepatnya mengarahkan atau memberikan solusi dan apa yang diinginkan oleh konsumen maka kualitas pelayanan pada bisnis tersebut dapat dipastikan tidak baik atau buruk. Secara tidak langsung akan menyebabkan konsumen tidak puas kemudian melakukan pembicaraan secara mulut ke mulut mengenai hal ini yang akan sangat menakutkan efek untuk kedepannya bahkan bisnis kuliner tersebut akan berumur pendek akibat hal tersebut.

\section{Indikator Kualitas Pelayanan}

Menurut Kotler dalam (Priansa, 2017:56) ada lima dimensi kualitas pelayanan, yaitu sebagai berikut.

1. Keandalan (Reliability), merupakan kebisaan atau keahlian untuk menyediakan perihal yang dijanjikan dengan laju dan dapat meyakinkan.

2. Keresponsifan (Responsiveness), merupakan kebisaan atau keahlian seseorang untuk mengasih perihal dengan laju untuk membantu yang menginginkan. 
3. Keyakinan (Confidence), merupakan kebisaan atau keahlian tenaga manusia untuk menimbulkan kepercayaan dan keyakinan.

4. Empati (Emphaty), berkaitan dengan kebisaan atau kompeten sebuah organisasi dan tenaga manusianya untuk bersimpati kepada apa yang dirasakan pihak atau orang yang memerlukan pelayanan.

5. Berwujud (Tangible), berkaitan dengan fasilitas fisik yang tampak dengan mata, peralatan dan media komunikasi.

\section{Kepuasan Konsumen}

Kepuasan konsumen adalah bawaan perasaan dalam hati seseorang mau itu senang atau kecewa yang asalnya dari penilaian antara hasil dari barang atau jasa yang diberikan dengan barang atau jasa yang diharapkan atau yang menjadi pengalaman pribadi dari orang tersebut (Aswad, Realize, \& Wangdra, 2019:79). Kepuasan konsumen dapat tercapai bila ekspetasi dari konsumen untuk berbagai hal seperti promosi yang sesuai dan kualitas pelayanan yang luar biasa diperoleh maka terdapat kepuasan konsumen ini. Kepuasan konsumen sangat penting karena langsung berhubungan dengan kelangsungan hidup dari bisnis kuliner itu sendiri. Bila konsumen merasa puas maka akan melakukan kunjungan kembali untuk kedepannya, hal inilah yang sangat diinginkan oleh pebisnis kuliner.

\section{Indikator Kepuasan Konsumen}

Menurut (Priansa, 2017:210) ada beberapa indikator untuk mengukur terjadinya kepuasan konsumen atau tidak pada suatu perusahaan adalah sebagai berikut.

\section{Harapan}

Tentu seseorang membeli barang atau jasa memiliki harapan yang tinggi terhadap barang atau jasa yang dibeli semakin besar harapan yang ada maka kemungkinan dikecewakan semakin besar.

2. Kinerja

Hasil kerja dari orang yang memberikan atau menjual barang dan jasa juga dapat menjadi tolak ukur untuk mengetahui kepuasan konsumen.

3. Perbandingan

Untuk mengetahui suatu produk atau jasa yang satu dengan yang lainnya harusnya ada yang dibanding-bandingkan untuk mengetahui punya siapa yang terbaik.

4. Pengalaman

Tentu seseorang pasti memiliki pengalaman untuk mendapatkan suatu barang dan jasa otomatis memiliki gambaran bagaimana kualitas dari barang atau jasa tersebut sehingga bila yang diperoleh kini lebih buruk dari 


pengalamannya sebelumnya
maka dapat pastikan
ketidakpuasan terjadi.

5. Konfirmasi

Bagaimana cara komunikasi dari seorang penjual atau penyedia jasa terhadap calon pembeli, bila seseorang telah membeli produk atau jasa tersebut maka dibutuhkannya konfirmasi atau memastikan apakah jadi tidaknya transaksi tersebut.

\section{Kerangka Pemikiran}

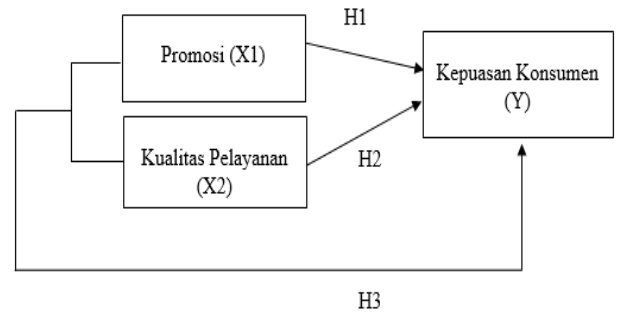

Gambar 1. Kerangka Pemikiran

\section{METODE PENELITIAN Desain Penelitian}

Desain penelitian adalah proyek untuk para peneliti. Penelitian ini menggunakan proyek penelitian untuk menguji potensi hubungan antara variabel yang terkait dalam penelitian ini.

\section{Populasi dan Sampel}

Objek atau nilai yang akan diteliti dalam populasi ini adalah unit analisis atau elemen populasi. Populasi dalam penelitian ini adalah 1500 konsumen yang berkunjung ke Restoran Bakso Lapangan Tembak
Senayan yang diambil pada bulan September 2019.

Penentuan sampel dalam penelitian ini menggunakan teknik sampling yaitu Purposive Sampling. Sampel pada penelitian ini sebanyak 100 responden.

\section{Metode Pengumpulan dan} Analisis Data

Alat yang digunakan dalam pengumpulan data pada penelitian ini adalah menggunakan kuesioner untuk mengumpulkan jawab dari para responden. Cara pengumpulan data pertama kuesioner tersebut diletakkan diatas meja kemudian untuk pengisian diminta kepada konsumen setelah konsumen selesai menikmati hidangannya yang diarahkan oleh karyawan restoran. Analisis data akan digunakan uji kualitas data, uji asumsi klasik dan uji pengaruh secara pisah atau pun sama-sama.

\section{HASIL DAN PEMBAHASAN Hasil Uji Validitas}

Pearson digunakan untuk menguji validitas. Signifikannya setingkat 0,05 serta dua arah pengujian dan jumlah responden data (n) sebanyak 100 maka $r$ tabel diperoleh nilai sebesar 0,182 . Hasil uji kolerasi variabel Promosi (X1) dan Kualitas Pelayanan (X2) dan Kepuasan Konsumen (Y) yang menunjukkan hasil $\mathrm{r}$ hitung lebih 
besar daripada $r$ tabel sehingga dapat disimpulkan semua variabel pada penelitian ini valid.

\section{Hasil Uji Reliabilitas}

Hasil uji reliabilitas pada semua variabel menunjukkan angka diatas 0,6 maka dapat disimpulkan bahwa semua variabel dalam penelitian ini dinyatakan reliabel atau dapat dipercaya. Sehingga untuk pengujian selanjutnya dapat dipercaya tidak perlu diragukan

berdasarkan tabel diatas dapat disimpulkan bahwa hasil uji Kolmogorov-Smirnov tersalur normal karena memperlihatkan angka signifikan Asymp. Sig. (2tailed) sebesar 0,190 lebih tinggi dari nilai alpha $(0,05)$. kembali untuk reliabelnya, maka peneliti dapat dengan tenang untuk melakukan penelitian ini lebih lanjut.

\section{Hasil Uji Asumsi Klasik Hasil Uji Normalitas}

Uji normalitas dalam penelitian dapat dilakukan dengan uji Kolmogorov-Smirnov seperti tabel 1 sebagai berikut.

Uji Varience Inflation Factor (VIF) digunakan untuk mengetahui apakah terjadinya multikolinearitas antara variabel bebas atau independent variable.

\begin{tabular}{|c|c|c|c|}
\hline \multirow{4}{*}{$\begin{array}{l}\text { Hasil } \\
\text { Uji } \\
\text { Mult } \\
\text { ikoli } \\
\text { neari } \\
\text { tas }\end{array}$} & \multicolumn{3}{|c|}{ Tabel 1. Hasil Uji Kolmogorov-Smirnov } \\
\hline & \multicolumn{3}{|r|}{ Unstandardized Residual } \\
\hline & $\mathrm{N}$ & & 100 \\
\hline & Normal Parameters ${ }^{\mathrm{a}, \mathrm{b}}$ & Mean & .0000000 \\
\hline & & Std. Deviation & 4.05182615 \\
\hline & Most Extreme & Absolute & .075 \\
\hline & Differences & Positive & .048 \\
\hline & & Negative & -.075 \\
\hline & Test Statistic & & .075 \\
\hline & Asymp. Sig. (2-tailed) & & $.190^{\circ}$ \\
\hline
\end{tabular}


Tabel 2. Hasil Uji Multikolinearitas

\begin{tabular}{|c|c|c|c|}
\hline \multirow{2}{*}{\multicolumn{2}{|c|}{ Model }} & \multicolumn{2}{|c|}{ Collinearity Statistics } \\
\hline & & Tolerance & VIF \\
\hline \multicolumn{4}{|c|}{ (Constant) } \\
\hline & Promosi (X1) & .997 & 1.003 \\
\hline & Kualitas Pelayanan (X2) & .997 & 1.003 \\
\hline
\end{tabular}

a. Dependent Variable: Kepuasan Konsumen $(\mathrm{Y})$

Berdasarkan hasil tabel 2 diatas dapat disimpulkan bahwa hasil tolerance pada masing-masing variabel lebih tinggi dari 0,1 sedangkan nilai VIF lebih rendah dari 10, sehingga dapat disimpulkan bahwa penelitian ini tidak adanya multikolinearitas.

\section{Hasil Uji Heteroskedastisitas}

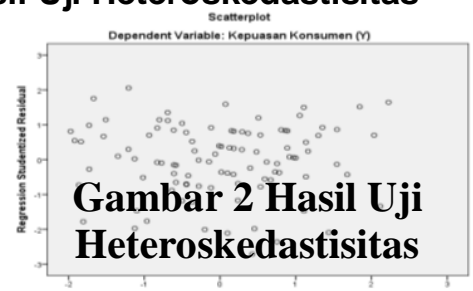

Pada gambar 2 bisa dilihat bahwa titik pada grafik tersebar secara acak tidak beraturan atau sembarang namun dengan angka lebih tinggi dari 0 maupun lebih rendah angka 0 dan sumbu $\mathrm{Y}$. Dengan ini dapat disimpulkan bahwa tidak terjadinya heteroskedastisitas dalam penelitian ini.

\section{Hasil Uji Pengaruh}

\section{Analisis Regresi Berganda}

Analisis regresi berganda berfungsi sebagai menguji pengaruh variabel bebas terhadap variabel terikat secara sendiri-sendiri maupun secara bersama-sama.

Tabel 3. Hasil Uji Regresi Berganda

\begin{tabular}{|c|c|c|c|c|c|c|c|}
\hline \multirow[b]{2}{*}{ Model } & \multicolumn{2}{|c|}{$\begin{array}{c}\text { Unstandardized } \\
\text { Coefficients }\end{array}$} & \multirow{2}{*}{$\begin{array}{c}\text { Standardized } \\
\text { Coefficients } \\
\text { Beta } \\
\end{array}$} & \multirow[b]{2}{*}{$\mathrm{T}$} & \multicolumn{3}{|c|}{$\begin{array}{l}\text { Collinearity } \\
\text { Statistics }\end{array}$} \\
\hline & $\mathrm{B}$ & Std. Error & & & Sig. & Tolerance & VIF \\
\hline 1 (Constant) & 29.051 & 3.656 & & 7.945 & .000 & & \\
\hline Promosi (X1) & .259 & .125 & .200 & 2.074 & .041 & .997 & 1.003 \\
\hline Kualitas & & & & & & & \\
\hline $\begin{array}{l}\text { Pelayanan } \\
\text { (X2) }\end{array}$ & .148 & .055 & .259 & 2.689 & .008 & .997 & 1.003 \\
\hline
\end{tabular}

a. Dependent Variable: Kepuasan Konsumen $(Y)$

(Sumber: Data primer diolah SPSS,2019) 
Berdasarkan pengolahan data pada tabel 3 diatas dapat diperoleh persamaan regresi sebagai berikut.

$$
Y=29,051+0,259 X 1+0,148 X 2
$$

\section{Analisis Koefisien Determinasi $\left(\mathbf{R}^{2}\right)$ \\ Pada analisis ini bertujuan untuk mengetahui seberapa besar kemampuan variabel bebas secara simultan memberikan pengaruh terhadap variabel terikat.}

Tabel 4. Koefisien Determinasi $\left(\mathrm{R}^{2}\right)$

\begin{tabular}{lcccc}
\hline Model & $\mathrm{R}$ & $\mathrm{R}$ Square & $\begin{array}{c}\text { Adjusted } \mathrm{R} \\
\text { Square }\end{array}$ & $\begin{array}{c}\text { Std. Error of the } \\
\text { Estimate }\end{array}$ \\
\hline 1 & $.318^{\mathrm{a}}$ & .101 & .083 & 4.093 \\
\hline a. Predictors: (Constant), Kualitas Pelayanan (X2), Promosi (X1) & \\
b. Dependent Variable: Kepuasan Konsumen (Y) & &
\end{tabular}

(Sumber: Data primer diolah SPSS,2019)

Pada tabel 4 nilai $R$ Square $\left(\mathrm{R}^{2}\right)$ yang diperoleh adalah sebesar 0,101 Ini berarti persen kontribusi variabel indenpenden dalam model regresi sebesar $10,1 \%$ sedangkan sebanyak $89,9 \%$ pengaruhi oleh variabel bebas lain yang tidak diteliti dalam penelitian ini.

\section{Hasil Uji Hipotesis} Hasil Uji t (Parsial)

Nilai t tabel dalam penelitian ini adalah 1,984.Berikut adalah hasil dari uji hipotesis secara sendirisendiri.

Tabel 5. Hasil Pengujian Hipotesis Secara Parsial (Uji t)

\begin{tabular}{|c|c|c|c|c|c|}
\hline \multirow[b]{2}{*}{ Model } & \multicolumn{2}{|c|}{$\begin{array}{l}\text { Unstandardized } \\
\text { Coefficients }\end{array}$} & \multirow{2}{*}{$\begin{array}{c}\text { Standardized } \\
\text { Coefficients } \\
\text { Beta }\end{array}$} & \multirow[b]{2}{*}{$\mathrm{T}$} & \multirow[b]{2}{*}{ Sig. } \\
\hline & B & Std. Error & & & \\
\hline 1 (Constant) & 29.051 & 3.656 & & 7.945 & .000 \\
\hline Promosi (X1) & .259 & .125 & .200 & 2.074 & .041 \\
\hline $\begin{array}{l}\text { Kualitas Pelayanan } \\
\text { (X2) }\end{array}$ & 148 & .055 & .259 & 2.689 & .008 \\
\hline
\end{tabular}

a. Dependent Variable: Kepuasan Konsumen $(\mathrm{Y})$

(Sumber: Data primer diolah SPSS,2019)

Nilai t-hitung untuk promosi $(2,074)$ melebihi nilai t-tabel $(1,984)$ atau nilai sig $\mathrm{t}(0,041)$ lebih kurang dari alpha $(0,05)$. Berdasarkan hasil yang diperoleh maka H0 ditolak dan $\mathrm{H} 1$ diterima 
untuk variabel promosi, dengan demikian maka secara parsial variabel promosi berpengaruh secara positif dan signifikan terhadap kepuasan konsumen. Nilai t-hitung untuk variabel kualitas pelayanan $(2,689)$ melebih nilai ttabel $(1,984)$ atau nilai sig $t(0,008)$ lebih kurang dari alpha $(0,05)$.
Berdasarkan hasil yang telah diperoleh maka $\mathrm{H} 0$ ditolak dan $\mathrm{H} 2$ diterima untuk kualitas pelayanan.

\section{Hasil Uji F (Simultan)}

Angka F-tabel senilai 3,09. Berikut ini adalah hasil yang diperoleh dari analisis uji hipotesis secara sama-sama.

Tabel 6. Hasil Pengujian Hipotesis Secara Simultan (Uji F)

\begin{tabular}{lrrrrr}
\hline Model & Sum of Squares & Df & Mean Square & F & Sig. \\
\hline 1 Regression & 183.328 & 2 & 91.664 & 5.471 & $.006^{\mathrm{b}}$ \\
Residual & 1625.312 & 97 & 16.756 & & \\
Total & 1808.640 & 99 & & & \\
\hline
\end{tabular}

a. Dependent Variable: Kepuasan Konsumen ( $\mathrm{Y}$ )

b. Predictors: (Constant), Kualitas Pelayanan (X2), Promosi (X1)

(Sumber: Data primer diolah SPSS,2019)

. Dapat dikatakan positif karena nilai F-hitung 5,471 melebihi dari nilai F- tabel senilai 3,07 dan dikatakan signifikan karena signifikansi dari variabel promosi dan kualitas pelayanan senilai 0,006 lebih rendah dari nilai alpha 0,05 . Maka dapat diketahui bahwa dalam hal ini variabel promosi dan kualitas pelayanan secara sama-sama berpengaruh positif dan signifikan terhadap kepuasan konsumen pada Restoran Bakso Lapangan Tembak Senayan.

\section{Pembahasan}

\begin{abstract}
Pengaruh Promosi terhadap Kepuasan Konsumen pada Restoran Bakso Lapangan Tembak Senayan

Dalam hasil penelitian ini diketahui variabel promosi berpengaruh signifikan dan positif secara parsial terhadap kepuasan konsumen pada Restoran Bakso Lapangan Tembak Senayan. Hasil penelitian ini mendukung penelitian yang dilakukan oleh (Manampiring et al., 2016:164) yang menyatakan bahwa variabel promosi berpengaruh positif dan signifikan terhadap kepuasan konsumen.
\end{abstract}


Pengaruh Kualitas Pelayanan terhadap Kepuasan Konsumen pada Restoran Bakso Lapangan Tembak Senayan

Dalam hasil penelitian ini diketahui variabel kualitas pelayanan berpengaruh signifikan dan positif secara parsial terhadap kepuasan konsumen pada Restoran Bakso Lapangan Tembak Senayan. Hasil penelitian ini mendukung penelitian yang dilakukan oleh (Aswad et al., 2019:84) yang menyatakan bahwa variabel kualitas pelayanan berpengaruh positif dan signifikan terhadap kepuasan konsumen.

\section{Pengaruh Promosi dan Kualitas} Pelayanan terhadap Kepuasan Konsumen pada Restoran Bakso

\section{Lapangan Tembak Senayan}

Dalam hasil penelitian ini diketahui variabel promosi dan kualitas pelayanan berpengaruh signifikan dan positif terhadap kepuasan konsumen pada Restoran Bakso Lapangan Tembak Senayan.Hasil penelitian ini mendukung penelitian yang dilakukan oleh (Fauzi, 2019:389) yang menyatakan bahwa variabel promosi dan kualitas pelayanan berpengaruh positif dan signifikan terhadap kepuasan konsumen.

\section{SIMPULAN}

1. Berdasarkan hasil uji $t$ pada penelitian memperoleh hasil yang menunjukkan terdapat pengaruh positif dan signifikan promosi terhadap kepuasan konsumen pada Restoran Bakso Lapangan Tembak Senayan dan kualitas pelayanan berpengaruh positif dan signifikan terhadap kepuasan konsumen pada Restoran Bakso Lapangan Tembak Senayan.

2. Berdasarkan hasil uji $\mathrm{F}$ variabel promosi dan kualitas pelayanan secara bersama berpengaruh positif dan signifikan terhadap kepuasan konsumen pada Restoran Bakso Lapangan Tembak Senayan.

\section{DAFTAR PUSTAKA}

Aswad, S., Realize, R., \& Wangdra, R. (2019). Pengaruh Harga Dan Kualitas Pelayanan Terhadap Kepuasan Konsumen Pengguna Air Bersih Masyarakat Kampung Air Batam Center. JIM UPB (Jurnal Ilmiah Manajemen Universitas Putera Batam), 6(2), 77. https://doi.org/10.33884/jimup b.v6i2.681

Fauzi, A. (2019). Pengaruh Promosi dan Kualitas Pelayanan terhadap Kepuasan Konsumen pada Pembelian Tiket Pesawat Garuda pada PT . Hamsa. 
Jurnal Ekonomi \& Ekonomi Syariah, E-ISSN : 2599-3410, 2(2), 378-391.

Hermawan, B., Basalamah, S., Djamereng, A., \& Plyriadi, A. (2017). Effect of Service Quality and Price Perception on Corporate Image, Customer Satisfaction and Customer Loyalty among Mobile Telecommunication Services Provider. IRA-International Journal of Management \& Social Sciences (ISSN 24552267), 8(1), 62. https://doi.org/10.21013/jmss.v 8.n1.p7

Manampiring, A. S., Tumbuan, willem J. A. ., \& Wenas, R. (2016). Analisis produk, harga, lokasi, promosi terhadap kepuasan konsumen pada kartu kredit pt. bank mandiri tbk. manado. Jurnal EMBA, 23031174.

mardizal, im. (2017). Pengaruh Kualitas Pelayanan, Harga Dan Promosi Terhadap Kepuasan Konsumen Pada Golden Futsal Simpang Haru Padang.

Economica, 5(2), 128-133. https://doi.org/10.22202/econo mica.2017.v5.i2.418

Pelupessy, M. M. (2018). Analisis Pengaruh Promosi Dan Harga
Terhadap Keputusan

Pembelian Besi Putih Di Kota

Ambon ( Studi Empiris pada

Toko Besi Putih Asli (Khas)

Maluku Di Kota Ambon). 6

Priansa, D. J. (2017). Perilaku konsumen dalam persaingan bisnis kontemporer.

Roring, F., Oroh, S., \& Gulla, R. (2015). Analisis Harga, Promosi, Dan Kualitas Pelayanan Terhadap Kepuasan Konsumen Pada Hotel Manado Grace Inn. Jurnal Riset Ekonomi, Manajemen, Bisnis Dan Akuntansi, 3(1), 13131322. 